\title{
Educational managers' opinions regarding the in- service training in Turkey: A case study of the Agri Province
}

\author{
Ihsan Nuri DEMiREL \\ Faculty of Education, Department of Educational Sciences Educational Management Inspection, Planning and \\ Economy Department. Ağrı Ibrahim Cecen University, Turkey.
}

Received 03 February, 2015; Accepted 10 June, 2015

\begin{abstract}
In this study, research was carried out in order to find out whether the certificate system which requires attendants of in-service training is adequate; whether their achievements are sufficiently evaluated in the appointment and ranking processes; whether in-service training is accepted as both a right and a responsibility of the institutions; whether the units responsible for the coordination of inservice training on a national and local level in Turkey are sufficient, and whether human relations are deemed important in in-service training programs as part of views of the Directors of the Agri National Education Directorate, the Principals and Vice Principals of Primary-Secondary Schools in the context of Administration and Supervision. The directors administered a survey which contained information on in-service training in order to determine their level of knowledge on this training in terms of administration and supervision. The sample for the research is composed of 105 directors, 30 of these directors are principals, and the others are vice-principals, from the directors of Agri National Education. According to the findings of the research; it was seen that the directors answered the questions containing information on in-service training with variable rates.
\end{abstract}

Key words: In-service training, human relations, Turkish Educational System, Agri Province, Turkey.

\section{INTRODUCTION}

The certificate system that is required for in-service training attendants must be functionalized and used in their appointment and ranking processes. It must be agreed upon that attending in-service training sessions is both a right and a responsibility. The units that are responsible for the coordination of in-service training must be developed. In-service training programs must be provided with themes that improve human relations. It is necessary to state what rights achievers will gain at the end of the program, and to provide them with sufficient financial sources, in a reasonable time, in order to receive favorable results in in-service training activities (Küçükahmet, 1986).

Following developments and innovations related to public service and technological developments is of great interest to those who conduct their jobs in a professional

E-mail: indemirel@yahoo.com.

Authors agree that this article remain permanently open access under the terms of the Creative Commons Attribution License 4.0 International License 
manner. Taking into consideration the fact that some knowledge and skills are gained within the service, and considering that in-service training is a sort of internship, it must be remembered that there might be some jobs which can be learnt after starting the service (Bilgin, 2004).

The fact that those who were previously promoted from teaching positions to director positions in the National Education directorates or central organization of the Ministry are afterwards returned to teaching positions is known to create away from the area and such compliance some problems. What should be done is to pay sufficient attention to in-service training by including qualities such as fund of knowledge, achievements and qualifications, as well as a certain professional time into objective criteria (Taymaz, 1981).

Directors need to be trained in in-service training programs continually due to the necessity to keep up with swiftly-developing technology that causes fundamental changes in almost all parts of social life (Erki, 1988).

There is a great need for in-service training in order to reach the previously set main goals, in terms of setting objectives for the institution, elucidating work requirements, setting the qualities that personnel must have, and propounding in-service training requirements (Karabaş, 1989).

In-service training is generally agreed upon to be a means of earning a sense of cooperation which is necessary for efficient group work, knowledge and skills pertaining to basic jobs of the organization, and developing the skill of adaptation to changing conditions (Kocabaş, 1993).

There is a strong correlation between in-service training and development. This sort of idea of education is the key to modernization. The effectiveness and the productiveness of the training process explain the effectiveness of the efforts in development and improvement substantially (Erişen, 1997).

A qualified department of education, which actively takes part within institutions, is highly recommended as part of improving in-service training in order to insure personnel competency, satisfying the learners' desire for knowledge via developed teaching techniques, and producing people who are able to establish positive dialogues in interpersonal relations (Kantek, 1998; Koç, 2013)

For personnel to fulfill their responsibilities more effectively and productively, they need to be trained continually and, in return, to keep up with the changes occurring within or outside the organization. This objective can be achieved by resorting to in-service training activities (Ekşi, 2001).

People with pre-training, which is necessary for taking up any job, have to follow developments and changes in their field in order to pursue their careers and make progress in their chosen career. This is enabled by inservice training activities (Oktay, 2007).

It is within the scope of the responsibilities of universities to train teachers and directors of formal education institutions within service. Every member of staff in the education system shares their knowledge, experiences, and observations with each other in inservice training activities (Başaran, 1993).

The training that one goes through during the period of time one is in service in order to increase the quality of produced goods and services, to increase the efficiency of production, to decrease institutional loss and to enable the institution to renew itself is called in-service training (Sağlam, 2008).

It is in-service training activity that allows one to develop a sense of security in their career, to lift their spirits, to maximize their level of prosperity, to seize an opportunity to move upwards in the hierarchy, and to pursue their lives in an environment of communication with open pores, and bring functionality to the development in this process (Adem, 1981; Arslan, 2011).

Problems, which cannot be solved only with skills taught at schools, are encountered in all fields of occupation. It is usually impossible to apply a training program which requires employing profoundly expensive machines and devices in schools. These kinds of deficiencies in the formal education process can be compensated by in-service training (Kıncal, 2001).

However, in-service training activities, which are not well organized, have got some drawbacks. In-service training activities which are not based on the real needs of the organization and personnel, which are organized as a means of a trip or to show-off have got no benefits (Başaran, 1985).

\section{METHOD}

The content of the survey forms used to gather data related to the views of the Agri National Education Directors on in-service training activities in terms of administration and supervision was developed in accordance with the aim of the research (Karasar, 2005). The survey includes 15 questions. At the beginning of the study, a pilot test was applied. After the pilot test application, 10 questions were eliminated. The survey forms were habilitated for the information process technique by conferring with the opinions of the personnel who were knowledgeable about the issue. According to the data gather from results of the trial, it was seen that some questions did not work. Inoperable questions were excluded from the survey form in order to enable validity which is the expediency degree of an assessment and evaluation instrument, and reliability which is the consistency criterion for an assessment and evaluation instrument; and then the content and arrangement of the survey form were given the final shape. Data gathered from survey forms filled by Agri National Education directors was assessed in accordance with the aim of the research, and a conclusion of the same attempted. Before drawing a conclusion, the data gathered from surveys was transformed into certain charts by the researcher. These charts 
Table 1. Variance of the schools included in the sample according to their number.

\begin{tabular}{lcc}
\hline School type & No & $\%$ \\
\hline High Schools and Equivalents & 14 & 36,84 \\
Primary Schools & 24 & 63,15 \\
General Total & 38 & 100 \\
\hline
\end{tabular}

Table 2. The variance of the experimental subjects in the sample according to their duties.

\begin{tabular}{lcc}
\hline Duty & F & $\%$ \\
\hline Principal & 30 & 28,57 \\
Vice Principal & 75 & 71,42 \\
Total & 105 & 100 \\
\hline
\end{tabular}

served as a facilitating factor in drawing a conclusion. Survey takers were asked to mark degree of accuracy of sentences related to views of Agri National Education Directors on in-service training activities in terms of administration and supervision as "Never", "Partially", "Quite" and "Exactly". These degrees were graded, respectively, 1, 2, 3 and 4 . Thus, degrees of accuracy were converted into percentages.

\section{Population and sample}

The subjects of the research consisted of school directors who worked in the academic year of 2008-2009 in schools affiliated with the Agri National Education Directorate. The Agri National Education Directorate's list of institutions was taken as a basis for setting the population. It is possible to pronounce the homology of the sample with the population as reaching the vast majority of directors as fundamental. The research was carried out on two experimental groups. One of them consisted of principals and the other of vice-principals from the directors of the Agri National Education Directorate. The aim was to include all the schools and directors of the National Education Directorate in Agri into the sample, and this was achieved substantially. Moreover, the fractions of numbers were not recorded on the charts while numbering the percentages of the research. Only two numbers after the decimal point of all the percentages were recorded on the charts. The reason why the rate of a hundred per cent (100\%) was not reached is the lack of fractional numbers.

Just as the schools above included in the sample, the National Education Directorate directors were also included in the sample. The National Education Directorate was not recorded as it is not a school. The subjects to whom the surveys would be given in the schools on which the research was carried out were chosen as follows: The survey was given to almost all of the directors of Agri National Education Directorate and the schools in Agri, which were the part of the sample. All experimental subjects were administered the same survey.

The number of the directors to whom the survey was administered was 105.30 of this number were principals and 75 were vice-principals (Tables 1 and 2).

\section{Data gathering}

All of the 38 institutions answered the survey. None of the surveys were invalid. The survey was administered to almost all the directors working in schools in Agri. However, although there were no vice-principals who refused to answer the survey, some principals did not want to answer the survey. The survey forms were distributed to the directors by the researcher in person within the framework of the permission taken from Agri Governorate, and with the knowledge and permission of the National Education Directorate, and the directors were asked to fill the survey forms in due form and hand in to the researcher.

\section{Problem}

The research was conducted in order to find out on what level the views of Agri National Education Directors on In-Service Training in Administrative and Supervisory terms are.

\section{Sub-problem}

What level are the views of the Director of the National Education, and the principals of primary and secondary schools, out of the directors of Agri National Education Directors, on in-service training activities in administrative and supervisory terms?

\section{Premises}

1- Pre-testing for developing the surveys is sufficient.

2- Expert opinions resorted for developing the surveys are sufficient.

3- Views of Agri National Education Directors which were consulted for the research reflect the reality.

4- Chosen research method is compatible with the aim of the research.

5- The sample's degree of representing the population is favorable.

6- The survey and the questions in the survey which were employed to gather data are valid and reliable.

7- It is assumed that the data provided is valid and reliable.

\section{Restrictions}

1- This research was restricted to in-service training in administrative and supervisory terms and views of the Agri National Education Directors.

2- This research was restricted to the views of the Director of Agri National Education, deputy directors of Agri National Education and, the principals and vice-principals of high schools, high schoolequivalents, and primary schools, and affiliated with the National Education Directorate in the Centrum of Agri.

3- This research was restricted to accessible resources and surveys which were used as means for data gathering.

\section{FINDINGS}

In this section, the views of the Agri National Education directors on in-service training in administrative and supervisory terms have been given with the help of charts. The directors were asked to mark the degree of 
Table 3.The certificate system required for in-service training (IST) attendants is sufficient.

\begin{tabular}{|c|c|c|c|c|c|c|}
\hline \multirow[b]{2}{*}{ Duty } & \multicolumn{5}{|c|}{ Degree of accuracy } & \multirow[b]{2}{*}{$\begin{array}{c}\text { GENERAL } \\
\text { TOTAL }\end{array}$} \\
\hline & & $\begin{array}{c}\text { EXACTLY } \\
(4)\end{array}$ & $\begin{array}{c}\text { QUITE } \\
(3)\end{array}$ & $\begin{array}{c}\text { PARTLY } \\
(2) \\
\end{array}$ & $\begin{array}{c}\text { NEVER } \\
\text { (1) }\end{array}$ & \\
\hline Primary Schools & 24 & 63,15 & $\begin{array}{c}11 \\
36,66\end{array}$ & $\begin{array}{c}9 \\
30\end{array}$ & $\begin{array}{c}1 \\
3,33\end{array}$ & $\begin{array}{c}30 \\
28,57\end{array}$ \\
\hline General Total & 38 & 100 & $\begin{array}{l}15 \\
20\end{array}$ & $\begin{array}{c}34 \\
45,33\end{array}$ & $\begin{array}{c}14 \\
18,66\end{array}$ & $\begin{array}{c}75 \\
71,42\end{array}$ \\
\hline TOTAL & $\mathrm{F}$ & 21 & 26 & 43 & 15 & $\begin{array}{l}105 \\
100\end{array}$ \\
\hline
\end{tabular}

Table 4. The achievements of those who attend IST activities are sufficiently evaluated in appointment and rating processes.

\begin{tabular}{|c|c|c|c|c|c|c|}
\hline \multirow[b]{2}{*}{ Duty } & \multicolumn{5}{|c|}{ Degree of accuracy } & \multirow[b]{2}{*}{$\begin{array}{l}\text { GENERAL } \\
\text { TOTAL }\end{array}$} \\
\hline & & $\begin{array}{c}\text { EXACTLY } \\
(4)\end{array}$ & $\begin{array}{l}\text { QUITE } \\
\text { (3) }\end{array}$ & $\begin{array}{l}\text { PARTLY } \\
\text { (2) }\end{array}$ & $\begin{array}{c}\text { NEVER } \\
\text { (1) }\end{array}$ & \\
\hline \multirow{2}{*}{ PRINCIPAL } & $\mathrm{F}$ & 9 & 4 & 8 & 9 & 30 \\
\hline & $\%$ & 30 & 13,33 & 26,66 & 30 & 28,57 \\
\hline \multirow{2}{*}{ VICE- PRINCIPAL } & $\mathrm{F}$ & 11 & 15 & 27 & 22 & 75 \\
\hline & $\%$ & 14,66 & 20 & 36 & 29,33 & 71,42 \\
\hline TOTAL & $\mathrm{F}$ & 20 & 19 & 35 & 31 & $\begin{array}{l}105 \\
100\end{array}$ \\
\hline
\end{tabular}

accuracy of the sentences related to views on in-service training activities in terms of administration and supervision as "Never", "Partly", "Quite" and "Exactly". As previously stated above, these degrees were graded respectively, 1,2, 3 and 4 . Thus, the degrees of accuracy were converted into percentages. The views of the directors on in-service training in administrative and supervisory terms were shown as charts. The choices of "exactly" and "quite" were regarded as "favorable" choices, the accrual degrees of which are high.

As seen in Table 3, there were 9 of the principals who chose "exactly", 9 of them who chose "partly", and 1 of them who chose "never". 12 of the vice-principals chose "exactly", 15 of them chose "quite", 34 of them chose "partly", and 14 of them chose "never". The expectations of $66 \%$ of the principals and $36 \%$ of vice-principals on this issue were met "favorably".

As seen in Table 4, there were 9 of the principals who chose "exactly", 4 of them chose "quite", 8 of them chose "partly", and 9 of them chose "never". 11 of the vice- principals chose "exactly", 15 of them chose "quite", 27 of them chose "partly", and 22 of them chose "never". The expectations of $43 \%$ of principals and $34 \%$ of viceprincipals on this issue were met "favorably."

As seen in Table 5, there were 6 of principals who chose "exactly", 4 of them who chose "quite", 13 of them who chose "partly", and 7 of them who chose "never". 15 of the vice-principals chose "exactly", 20 of them chose "quite", 27 of them chose "partly", and 13 of them chose "never". The expectations of $33 \%$ of the principals and $46 \%$ of the vice-principals on this issue were met "favorably."

As seen in Table 6, there were 2 of the principals who chose "exactly", 6 of them chose "quite", 13 of them chose "partly" and 9 of them chose "never". 3 of viceprincipals chose "exactly", 13 of them chose "quite", 42 of them chose "partly" and 17 of them chose "never". Expectations of $26 \%$ of principals and $21 \%$ of viceprincipals on this issue were met "favorably."

As seen in Table 7, there were 7 principals who chose 
Table 5. IST is considered to be both a right and a responsibility in the institutions.

\begin{tabular}{|c|c|c|c|c|c|c|}
\hline \multirow[b]{2}{*}{ Duty } & \multicolumn{5}{|c|}{ Degree of accuracy } & \multirow[b]{2}{*}{$\begin{array}{c}\text { GENERAL } \\
\text { TOTAL }\end{array}$} \\
\hline & & $\begin{array}{c}\text { EXACTLY } \\
(4)\end{array}$ & $\begin{array}{c}\text { QUITE } \\
\text { (3) }\end{array}$ & $\begin{array}{l}\text { PARTLY } \\
\text { (2) }\end{array}$ & $\begin{array}{c}\text { NEVER } \\
(1)\end{array}$ & \\
\hline \multirow{2}{*}{ PRINCIPAL } & $\mathrm{F}$ & 6 & 4 & 13 & 7 & 30 \\
\hline & $\%$ & 20 & 13,33 & 43,33 & 23,33 & 28,57 \\
\hline \multirow{2}{*}{ VICE- PRINCIPAL } & $\mathrm{F}$ & 15 & 20 & 27 & 13 & 75 \\
\hline & $\%$ & 20 & 26,66 & 36 & 17,33 & 71,42 \\
\hline \multirow[t]{2}{*}{ TOTAL } & \multirow[t]{2}{*}{$\mathrm{F}$} & \multirow[t]{2}{*}{21} & \multirow[t]{2}{*}{24} & \multirow[t]{2}{*}{40} & \multirow[t]{2}{*}{20} & 105 \\
\hline & & & & & & 100 \\
\hline
\end{tabular}

Table 6. The units responsible for the coordination of IST nationally and locally in Turkey are sufficient.

\begin{tabular}{|c|c|c|c|c|c|c|}
\hline \multirow[b]{2}{*}{ Duty } & \multicolumn{5}{|c|}{ Degree of accuracy } & \multirow[b]{2}{*}{$\begin{array}{c}\text { GENERAL } \\
\text { TOTAL }\end{array}$} \\
\hline & & $\begin{array}{c}\text { EXACTLY } \\
(4) \\
\end{array}$ & $\begin{array}{c}\text { QUITE } \\
(3)\end{array}$ & $\begin{array}{c}\text { PARTLY } \\
\text { (2) } \\
\end{array}$ & $\begin{array}{c}\text { NEVER } \\
(1)\end{array}$ & \\
\hline \multirow{2}{*}{ PRINCIPAL } & $\mathrm{F}$ & 2 & 6 & 13 & 9 & 30 \\
\hline & $\%$ & 6,66 & 20 & 43,33 & 30 & 28,57 \\
\hline \multirow{2}{*}{ VICE- PRINCIPAL } & $\mathrm{F}$ & 3 & 13 & 42 & 17 & 75 \\
\hline & $\%$ & 4 & 17,33 & 56 & 22,66 & 71,42 \\
\hline \multirow[t]{2}{*}{ TOTAL } & \multirow[t]{2}{*}{$\mathrm{F}$} & \multirow[t]{2}{*}{5} & \multirow[t]{2}{*}{19} & \multirow[t]{2}{*}{55} & \multirow[t]{2}{*}{26} & 105 \\
\hline & & & & & & 100 \\
\hline
\end{tabular}

Table 7. Human relations are paid sufficient attention to in IST programs.

\begin{tabular}{|c|c|c|c|c|c|c|}
\hline \multirow[b]{2}{*}{ Duty } & \multicolumn{5}{|c|}{ Degree of accuracy } & \multirow[b]{2}{*}{$\begin{array}{c}\text { GENERAL } \\
\text { TOTAL }\end{array}$} \\
\hline & & $\begin{array}{c}\text { EXACTLY } \\
(4)\end{array}$ & $\begin{array}{c}\text { QUITE } \\
\text { (3) }\end{array}$ & $\begin{array}{c}\text { PARTLY } \\
\text { (2) } \\
\end{array}$ & $\begin{array}{c}\text { NEVER } \\
\text { (1) }\end{array}$ & \\
\hline \multirow{2}{*}{ PRINCIPAL } & $\mathrm{F}$ & 7 & 11 & 10 & 2 & 30 \\
\hline & $\%$ & 23,33 & 36,66 & 33,33 & 6,66 & 28,57 \\
\hline \multirow{2}{*}{ VICE- PRINCIPAL } & $\mathrm{F}$ & 8 & 24 & 28 & 15 & 75 \\
\hline & $\%$ & 10,66 & 32 & 37,33 & 20 & 71,42 \\
\hline TOTAL & $\mathrm{F}$ & 15 & 35 & 38 & 17 & $\begin{array}{l}105 \\
100\end{array}$ \\
\hline
\end{tabular}

"exactly", 11 of them who chose "quite", 10 of them who chose "partly" and 2 of them who chose "never". 8 of the vice-principals chose "exactly", 24 of them chose "quite", 28 of them chose "partly", and 15 of them chose "never".
The expectations of $59 \%$ of the principals and $42 \%$ of the vice-principals on this issue were met "favorably."

1. Attitude of $66 \%$ of the principals and $36 \%$ of the vice- 
principals to the statement that the "certificate system required for In-Service Training (IST) attendants is sufficient" was favorable. Although the majority of the principals stated that the certificate system required for in-service training attendants is sufficient, it is remarkable that the vice-principals disagreed with this to a higher degree, and there was a significant dissensus between the directors.

2. Attitude of $43 \%$ of principals and $34 \%$ of vice-principals to the statement that "achievements of IST attendants were not sufficiently evaluated in the appointment and rating processes" was favorable. It is impossible to disagree with the consensus of the principals and viceprincipals on this issue. In fact, it is impossible to claim that the achievements of those who attend in-service training activities are evaluated sufficiently in the in processes of appointment and rating.

3. The attitude of $33 \%$ of the principals and $46 \%$ of the vice-principals to the statement that "IST is not considered both a right and a responsibility in institutions" was favorable. The directors have a consensus on the point of stating that in-service training is considered both a right and a responsibility in institutions.

4. The attitude of $26 \%$ of the principals and $21 \%$ of the vice-principals to the statement that "units should provide coordination of IST in Turkey on a national and local level" was favorable. It is obvious that the directors believe that the units that are responsible for the coordination of IST in Turkey on a national and local level are insufficient. It is impossible to disagree.

5. The attitude of $59 \%$ of the principals and $42 \%$ of the vice-principals to the statement that "IST programs pay sufficient attention to human relations" was favorable. The principals state that in-service training programs do not pay sufficient attention to human relations. However, the vice-principals disagree with their superiors on this issue.

\section{SUGGESTIONS}

1- If the statement "The certificate system required for attendants of IST is sufficient" is considered to be too utopian, it should be explained to our directors why it is necessary to move constantly until it gets to this point.

2- The statement "Achievements of IST attendants are evaluated sufficiently in the appointment and rating processes" should certainly be given a meaningful insight; because those who attend in-service training activities are generally adults. One point that adults care about, in a training program they go through, is its urgent usability in daily life. Adults have no patience when thinking about the future. It may not be a pleasant way to put it, but they may not have enough time to wait for a better future either, in terms of life span. Therefore, our directors should be told that it is certainly necessary in order to transform achievements of in-service training attendants into their advancement.

3- In contrast to the statement "IST is not considered both a right and responsibility in institutions", the fact that it is a necessity should be explained to our directors.

4- Our directors should be given through courses the idea that the statement "Units that are responsible for the coordination of IST in Turkey nationally and locally are sufficient" should be set as a goal.

5- The statement "IST programs pay sufficient attention to human relations" constitutes the spine of in-service training. It should be explained to our directors that an inservice training activity isolated from etiquette and deprived of human relations cannot be meaningful.

6- Study sample is an important indicator for similar regions. Thus, it can be applied to more detailed studies in the different provinces.

\section{Conflict of Interests}

The author has not declared any conflict of interests.

\section{REFERENCES}

Adem M (1981). Educational Planning. Ankara: Sevinç Press.

Arslan MA (2011). Opinions of Literature Teachers Related to Academic Training, In-Service Training and Organizational Socialization Process, Educ. Res. Rev. 9(23):1280-1290, Doi: 10.5897/ERR2014.1961

Başaran IE (1985). Employee Services Administration in Organisations. Ankara: Ankara University Press.

Başaran IE (1993). Turkey Education System. Ankara: Gül Press.

Bilgin KU (2004). Public Performance Management. Ankara: Turkey and Middle East Public Administration Institute.

Ekşi I (2009). In-Service Training Needs of School Principals. Kocaeli University, Institute of Social Sciences, Master's Thesis, Kocaeli.

Erişen Y (1997). Determination of In-service Formation Training Needs of The Teachers of Workshop and Vocational. Ankara University, Institute of Social Sciences, Curriculum and Instruction/Department of Program Development, Master's Thesis, Ankara.

Erki BS (1988). Problems in Banking Personnel Training and An InService Training Model. Ankara University, Institute of Social Sciences, PhD Thesis, Ankara.

Kantek F (1998). Dokuz Eylül University, Institute of Health Sciences, Investigation of In-Service Training Programs for nurses at İzmir State Hospitals, İzmir.

Karabaş AR (1989). Investigation of In-Service Training Programs. Anadolu University, Institute of Social Sciences, Master's Thesis, Eskişehir.

Karasar N (2005). Scientific Research Methods, Nobel Press, Ankara.

Kıncal R (2001). Introduction to Teaching Profession. Erzurum: Babil Pablication.

Koç H (2013) The Ideas of Geography Teachers About In-Service Geography Training Activities, Educ. Res. Rev. 8(7):322-337, Doi: $10.5897 / 2012.236$ 
Kocabaş I (1993). Technical Teachers' Views on The Management of Activities and The Determination of In-Service Training. Anadolu University. Institute of Social Sciences, Master's Thesis, Elazığ.

Küçükahmet L (1986). Teaching Principles and Methods. Second Edition, Ankara: Ankara University Education Faculty Publication.

Oktay A (2007). Introduction to Education. Ankara: Pegem Publication.
Sağlam A (2008). Introduction to Education. Ankara: Maya Academy. Taymaz H (1981). In-Service Training. Ankara: Ankara University Education Faculty Publication. 